\title{
Late Quaternary Morphotectonics of the Hetauda Dun, Nepal Sub Himalaya
}

\begin{abstract}
Kazuo Kimura
3-17-10, Kaigamori, Sendai City, 981, Japan
ABSTRACT
The Hetauda Dun, a tectonic valley in the Sub-Himalaya, is separated from the Gangetic plain by the Outer Churia Range. This range was upheaved in the late Pleistocene giving rise to the Dun valley. The tectonics of the area are characterised by fault propagation tectonics caused by the migration of the active front from the Central Churia Thrust (CCT) to the Himalayan Front Thrust (HFT). After the closure of the Dun, another active anticlinal structure related to thrust imbrication has developed in the central part of the valley on the hanging wall of the CCT. The crustal movement continues under the same stress field of the prior tectonic phase, characterised by the shortening of the Sub-Himalaya along the NNW-SSE direction.
\end{abstract}

\section{INTRODUCTION}

Dun valleys are wide intermontane basins in the Sub-Himalaya. Their landforms are remarkable for the investigation of the neotectonics of the Himalaya. These lenticular shaped longitudinal valleys located between the Mahabharat Range and the Churia Range represent the active front of the Himalayan belt and represent tectonic or structural depressions formed in the Post-Siwaliks time.

The most effective method for studying Quaternary crustal movements is to analyse the geomorphic units of these Dun valleys. Nakata (1972) investigated these Duns in north India and recognised three types of tectonic landforms: (1) landforms tilted towards the Himalayan Range in the re-entrant of the Sub-Himalaya, (2) landforms characterised by faultsteps around the northern boundary of the Sub-Himalaya with a zone of subsidence to the south, and (3) landforms characterised by fault-steps with a narrow rift zone around the northern boundary of the Sub-Himalaya. It appears that differential movements along the Main Boundary Thrust (MBT) and the Himalayan Front Thrust (HFT) have generated these types of landforms. Yamanaka and Yagi (1984) found that the geomorphological development of the Dun valley in Dang, mid-western Nepal, located on the footwall of the MBT, was due to subsidence during the late Quaternary. They classified the valley floor into four terraces formed by the valley fill deposits. The youngest terrace is synclinally folded exhibiting a remarkable deformation in the youngest sediments in the valley. The age of the fold is dated to be post last Glacial Stage ( the ${ }^{14} \mathrm{C}$ age of the terrace deposits at the centre of the valley was dated as $16,000-26,000$ yr B.P.)

These studies indicate that considerable lateral variations of recent tectonics along the Himalayan front exist. However, the origin of the Dun valleys and related tectonics is yet to be well documented. This paper discusses the origin and modifying processes of a dun valley, considering the distribution pattern and deformation of geomorphic surfaces, sedimentological characteristics of terrace deposits, and relationships between tectonics and geomorphic units.

\section{GEOMORPHIC UNITS}

The study area is located about $50 \mathrm{~km}$ southwest of Kathmandu (Fig. 1). It extends for $30 \mathrm{~km}$ in the WNW-ESE direction with a maximum width of 12 $\mathrm{km}$. The elevation of the valley ranges from 300 to $600 \mathrm{~m}$ above m.s.l. Towards the north of the valley, the Inner Churia Range attains heights ranging from 800 to 1200 metres. The Outer Churia Range, separating the Dun from the Gangetic Plain, is 700-900 $\mathrm{m}$ in elevation. 


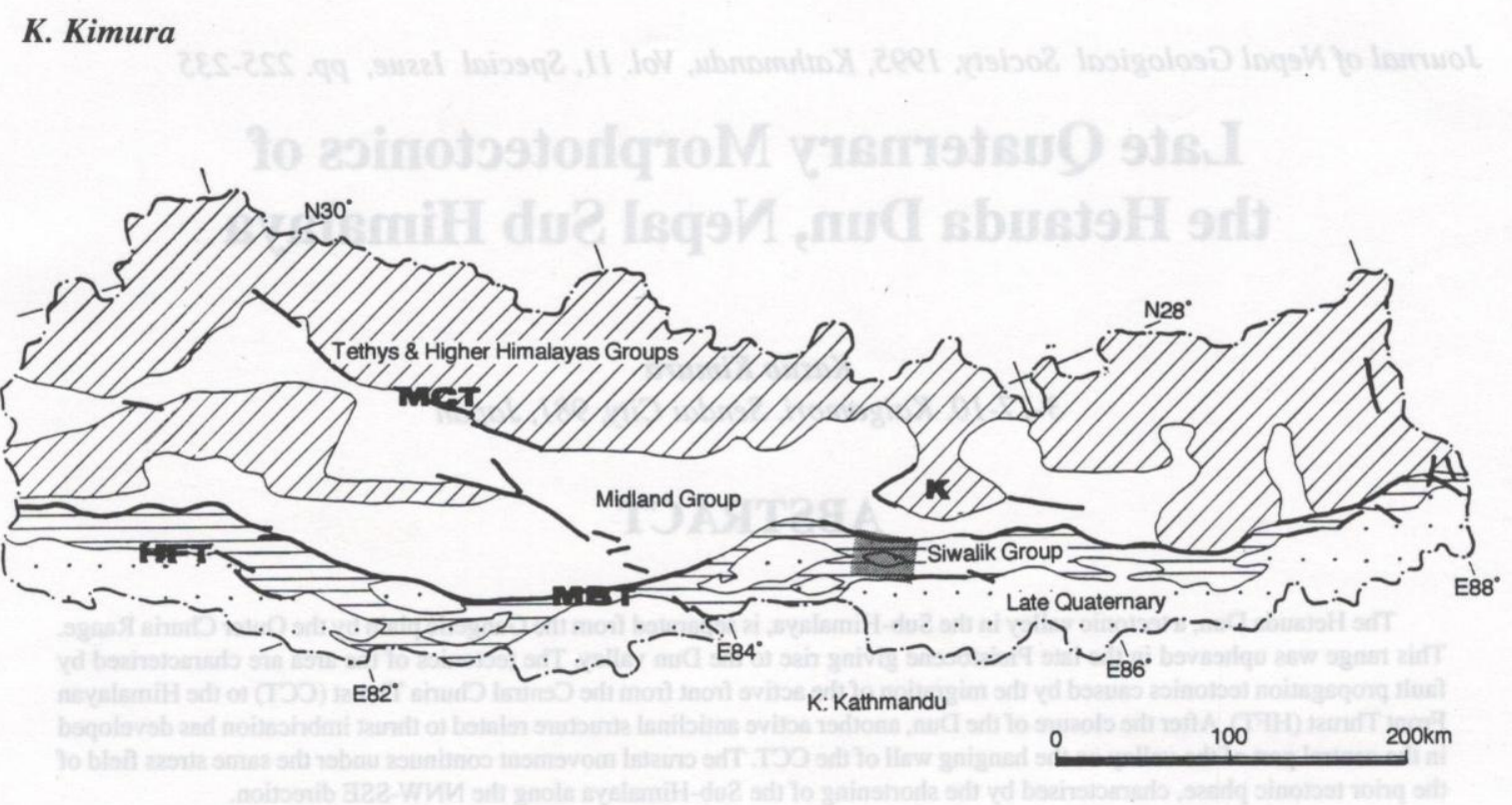

Fig. 1 Location of the study area

On the basis of aerial photo interpretation and field survey, the author has prepared a geomorphic map of the study area showing the distribution of the geomorphic surfaces, mainly consisting of fluvial terraces (Fig. 2). Twelve levels of geomorphological units are recognised in the study area. Fluvial terraces, except the recent alluvial surfaces, can be merged into four groups based on their morphological character, facies of terrace deposits and surface weathering (Kimura, in press) and are described below. The typical cross-sections through the terraces are shown in Fig. 3.

\section{THE HIGHEST EROSION SURFACE}

The Highest Erosion Surface is limited in the western part of the valley and lies about $150 \mathrm{~m}$ above the actual thalweg. The surface consists of thick (more than $100 \mathrm{~m}$ ), medium-sorted but poorly stratified gravel, unconformably overlying the Lower Siwaliks. Thick red-weathering crust (colour $1.25 \mathrm{yr}$ ) covers the surface.

\section{UPPER TERRACES}

The upper Terraces are located around the northern slope of the Outer Churia Range. Their height ranges from 100 to $130 \mathrm{~m}$ above the present river bed in the western part of the Dun, and decrease gradually towards the east. Though the terrace surfaces are dissected dendritically, they are flat and generally slope towards the northeast. The terrace sediments are mainly composed of well-sorted cobble beds with a total thickness of more than $100 \mathrm{~m}$. Red soils up to $10 \mathrm{~m}$ thick (colour $2.5 \mathrm{yr}$ ) are developed on the surface of these deposits. This soil colour indicates that the Upper Terraces have experienced cyclic climatic changes of the order of 100,000 years, and their age dates back to the middle Pleistocene.

\section{MIDDLE TERRACES}

The Middle Terraces are well developed on the northern slope of the Outer Churia Range and stand about $50 \mathrm{~m}$ above the alluvial plain in the southwestern part. The height of the terraces above the river bed decreases to the east and north. The terraces have fresh surfaces, but are entrenched by a few gullies. In the central part of the valley, the Middle Terraces converge into the Lower Terraces or the alluvial plain. Well-stratified gravel and sand unconformably overlie the deep red-weathered gravel. Total thickness of the deposit is generally less than $20 \mathrm{~m}$. Reddish 
Quaternary Morphotectonics of Hetauda Dun, Nepal
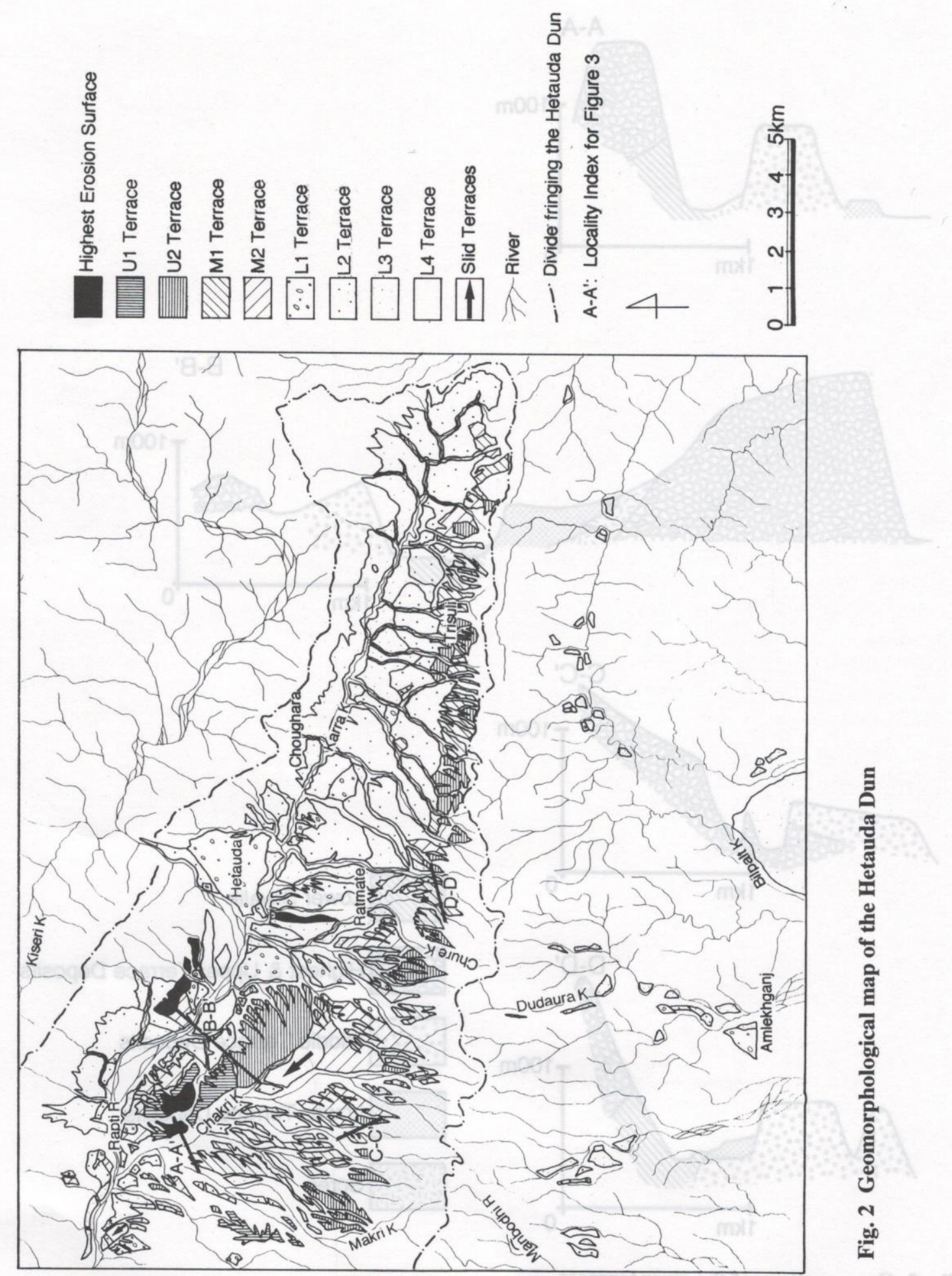

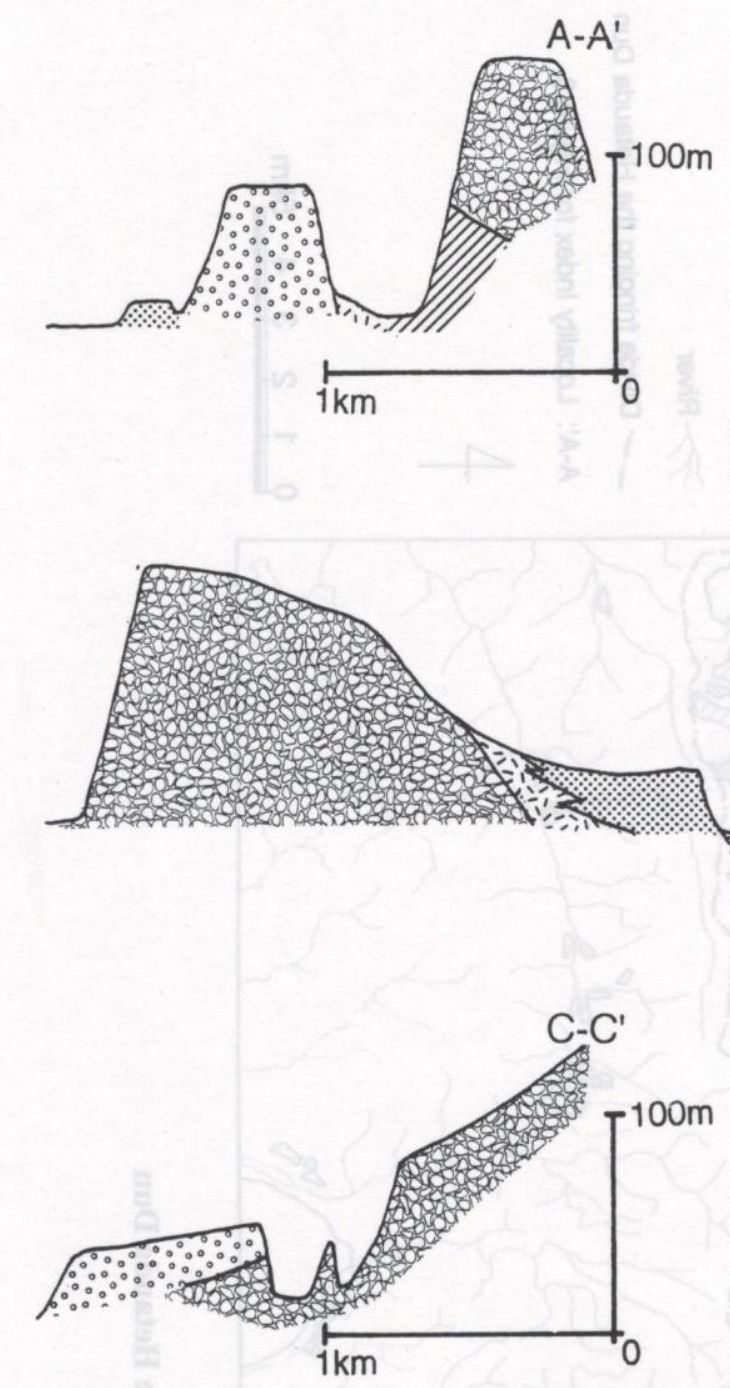

\section{B-B'}
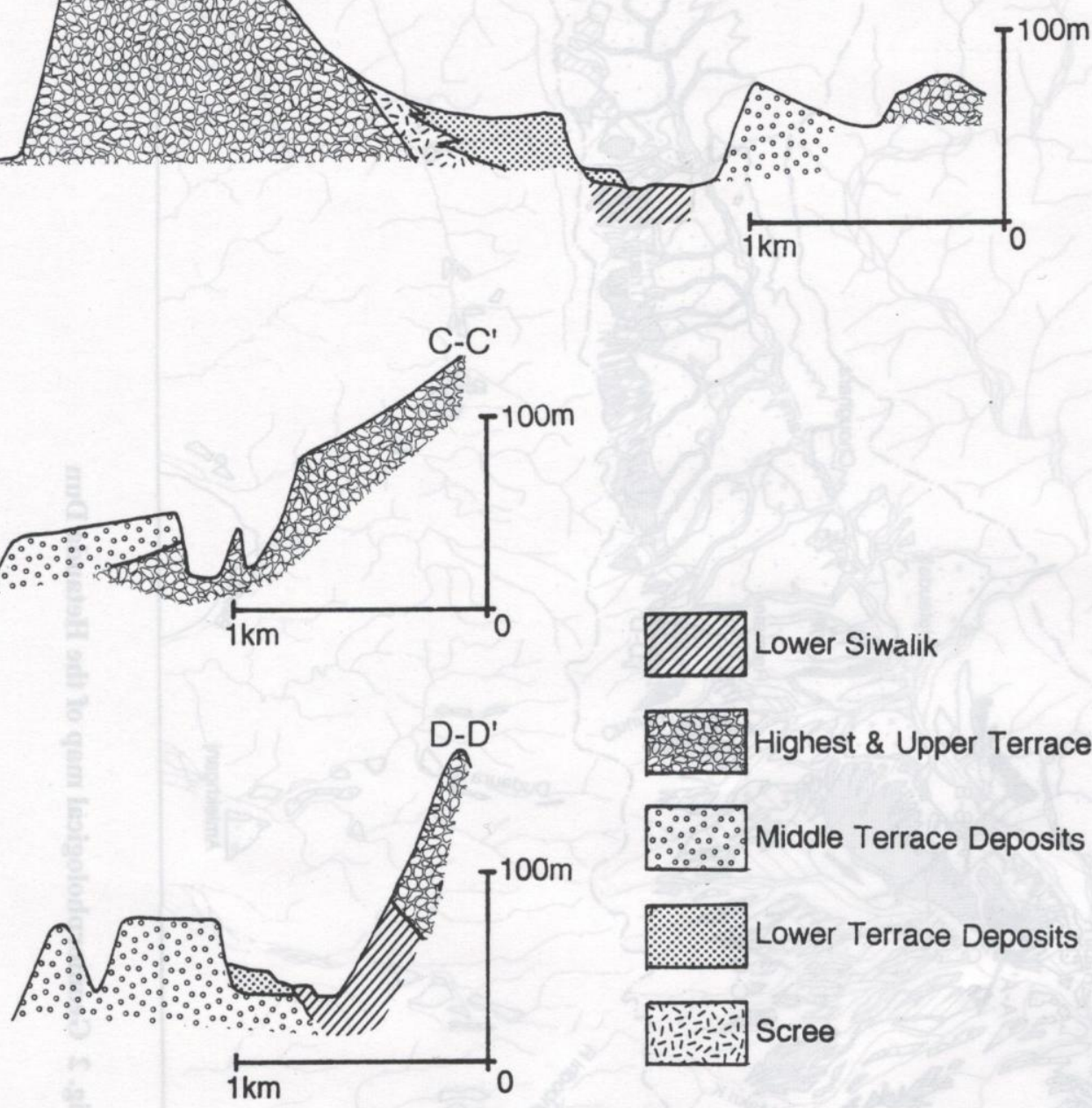

Lower Siwalik

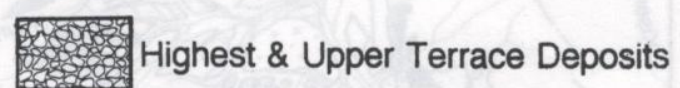

$\therefore \%$ Middle Terrace Deposits

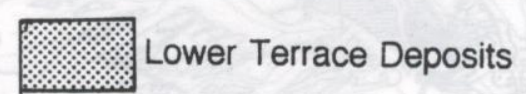

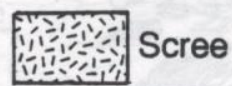

Fig. 3 Cross sections of the river terraces 
brown or orange coloured soils (colour $5 \mathrm{yr}$ ) are observed on the surface of these sediments. These soil colours indicate that the Middle Terraces were developed in the Last Interglacial Stage or the interstadial in the Last Glacial Stage.

\section{LOWER TERRACES}

The Lower Terraces occupy the eastern part (upper reaches) of the valley and lie several metres above the river bed. The terrace surfaces seem to still modifying themselves. Along the Karra Khola, terrace deposits include, in an ascending order, a basal gravelly bed of a few meter thickness; three sequences of lake-swamp deposits comprising peat, organic silt and sand of $10 \mathrm{~m}$ or more thickness; and about $10 \mathrm{~m}$ thick interfingering strata of gravel and sand. Weathering crusts have not matured on the Lower Terraces as those of the L1 terrace of the Dang Dun, which was formed 16,000-26,000 B.P. (Yamanaka and Yagi 1984). Therefore, the Lower Terraces must have started forming since the Last Glacial Stage and continued forming until the Holocene.

\section{STRUCTURES}

The active front of the central Nepal Himalaya is partitioned into three morphotectonic belts by the Central Churia Thrust (CCT) and the HFT (Tokuoka et al. 1986). These zones are: (1) the Inner Churia Range consisting of the northern belt of the Siwalik Group; (2) the Outer Churia Range comprising the southern belt of the Siwaliks; and (3) the Gangetic Plain filled up with the late Quaternary alluvium. The Hetauda Dun has developed between the Inner and Outer Churia ranges, where subordinate structures have developed parallel to the major tectonic lines (Fig. 4).

\section{CENTRAL CHURIA THRUST}

The Central Churia thrust trends in a WNW-ESE direction and diagonally crosses the Dun valley. It is
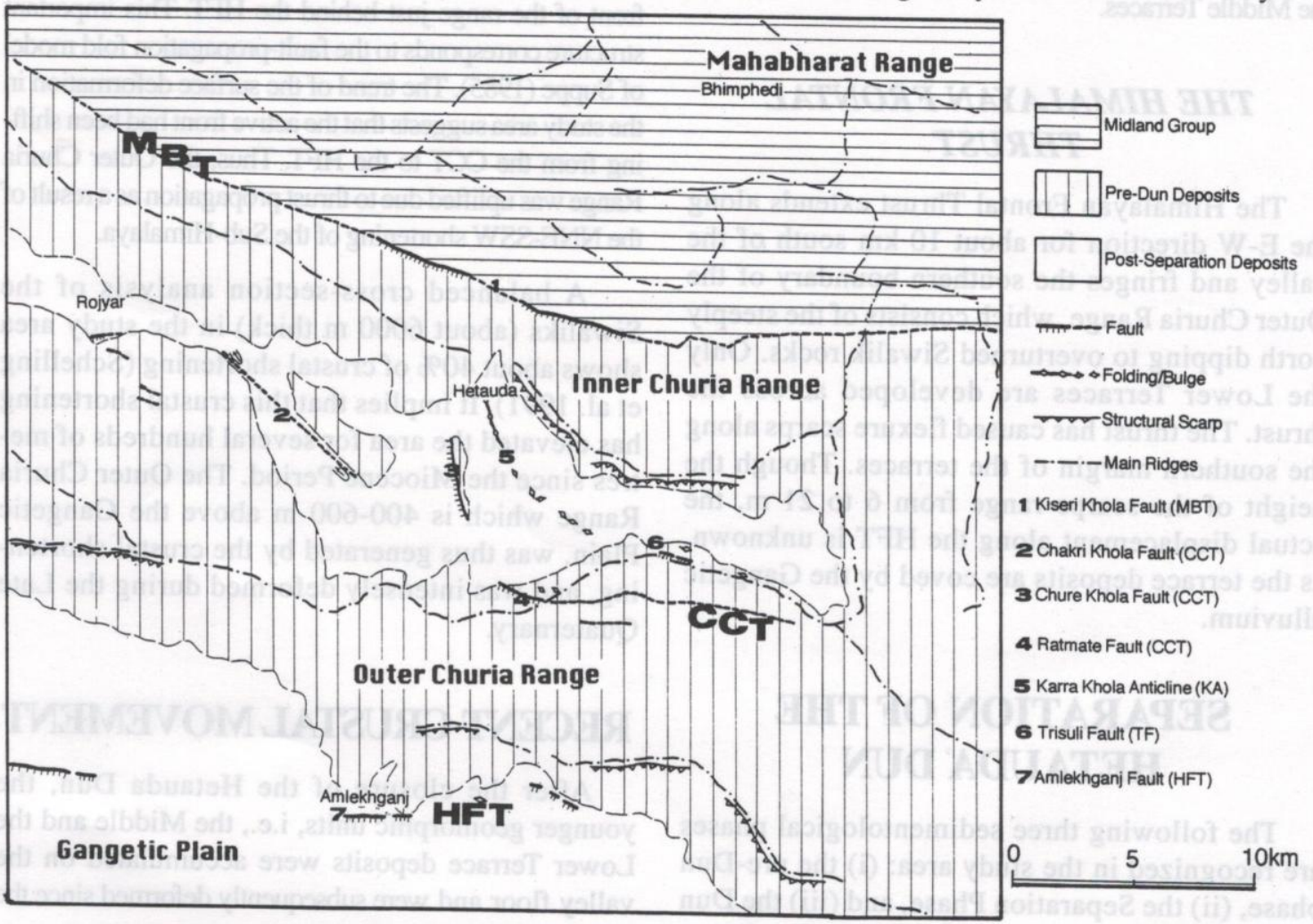

Fig. 4 Tectonic map of the Hetauda area 


\section{K. Kimura}

intermittently exposed in the valley, and branches out in some places. Along these thrusts, greenish shale of the Lower Siwaliks are thrust over younger gravelly layers of the Upper Siwaliks, terrace deposits or both. The fault bounds the southern margin of the Highest Surfaces, and causes buckling of the Upper Terraces as seen in the transverse profiles.

\section{CCT-ASSOCIATED HANGING WALL IMBRICATES}

CCT-associated hanging wall imbricates are substitute structures which are developing on the back slope of the CCT. The WNW-ESE trending and westerly plunging Karra Khola Anticline appears as a chain of tectonic bulges, winding on the valley floor. This anticline has upheaved the Lower Terraces for more than $10 \mathrm{~m}$. A WNW-ESE trending reverse fault, named the Trishuli Fault, is traceable with fault scarps of a few metres height near the crest of the Outer Churia Range near Trishuli Village. This Fault thrusts the Upper Terrace deposits over the Middle Terraces.

\section{THE HIMALAYAN FRONTAL THRUST}

The Himalayan Frontal Thrust extends along the E-W direction for about $10 \mathrm{~km}$ south of the valley and fringes the southern boundary of the Outer Churia Range, which consists of the steeply north dipping to overturned Siwalik rocks. Only the Lower Terraces are developed across the thrust. The thrust has caused flexure scarps along the southern margin of the terraces. Though the height of the scarps range from 6 to $21 \mathrm{~m}$, the actual displacement along the HFT is unknown, as the terrace deposits are coved by the Gangetic alluvium.

\section{SEPARATION OF THE HETAUDA DUN}

The following three sedimentological phases are recognized in the study area: (i) the pre-Dun phase, (ii) the Separation Phase, and (iii) the Dun Phase (Kimura, in press). The Separation Phase is the most important one as its study helps to understand the origin of the Hetauda Dun.

Evidence indicates that the separation of the Dun valley was due to tectonic processes. During the accumulation of Middle Terrace deposits, palaeocurrent direction reversed from south to north on the northern slope of the Outer Churia Range (Fig. 5). This reversal clearly shows that the uplift of the southern belt of the Siwaliks exceeded the rate of stream erosion, and cut off the channels flowing from the Lesser Himalaya into the Gangetic Plain. Hence, the Dun had separated from the Gangetic Plain by the Last Interglacial Stage or the interstadial in the Last Glacial Stage. The CCT has deformed the Upper Terraces, and controls the distribution of the higher surfaces, indicating crustal movements along this thrust during the Separation Phase. The Upper Terraces, however, slope steeper on the footwall of the CCT than on the hanging wall. The deformation of geomorphic units that took place before the Separation Phase is well documented near the crest of the Outer Churia Range (Fig. 6). On the southern slope of the Outer Churia Range, an anticline has developed in the front of the range just behind the HFT. This important structure corresponds to the fault-propagation fold model of Suppe (1985). The trend of the surface deformation in the study area suggests that the active front had been shifting from the CCT to the HFT. Thus, the Outer Churia Range was uplifted due to thrust propagation as a result of the NNE-SSW shortening of the Sub-Himalaya.

A balanced cross-section analysis of the Siwaliks (about $6000 \mathrm{~m}$ thick) in the study area shows about $40 \%$ of crustal shortening (Schelling et al. 1991). It implies that this crustal shortening has elevated the area for several hundreds of metres since the Miocene Period. The Outer Churia Range which is $400-600 \mathrm{~m}$ above the Gangetic Plain, was thus generated by the crustal shortening, and was intensely deformed during the Late Quaternary.

\section{RECENT CRUSTAL MOVEMENT}

After the closure of the Hetauda Dun, the younger geomorphic units, i.e., the Middle and the Lower Terrace deposits were accumulated on the valley floor and were subsequently deformed since the Last Glacial Stage. 
$\mathrm{N}$
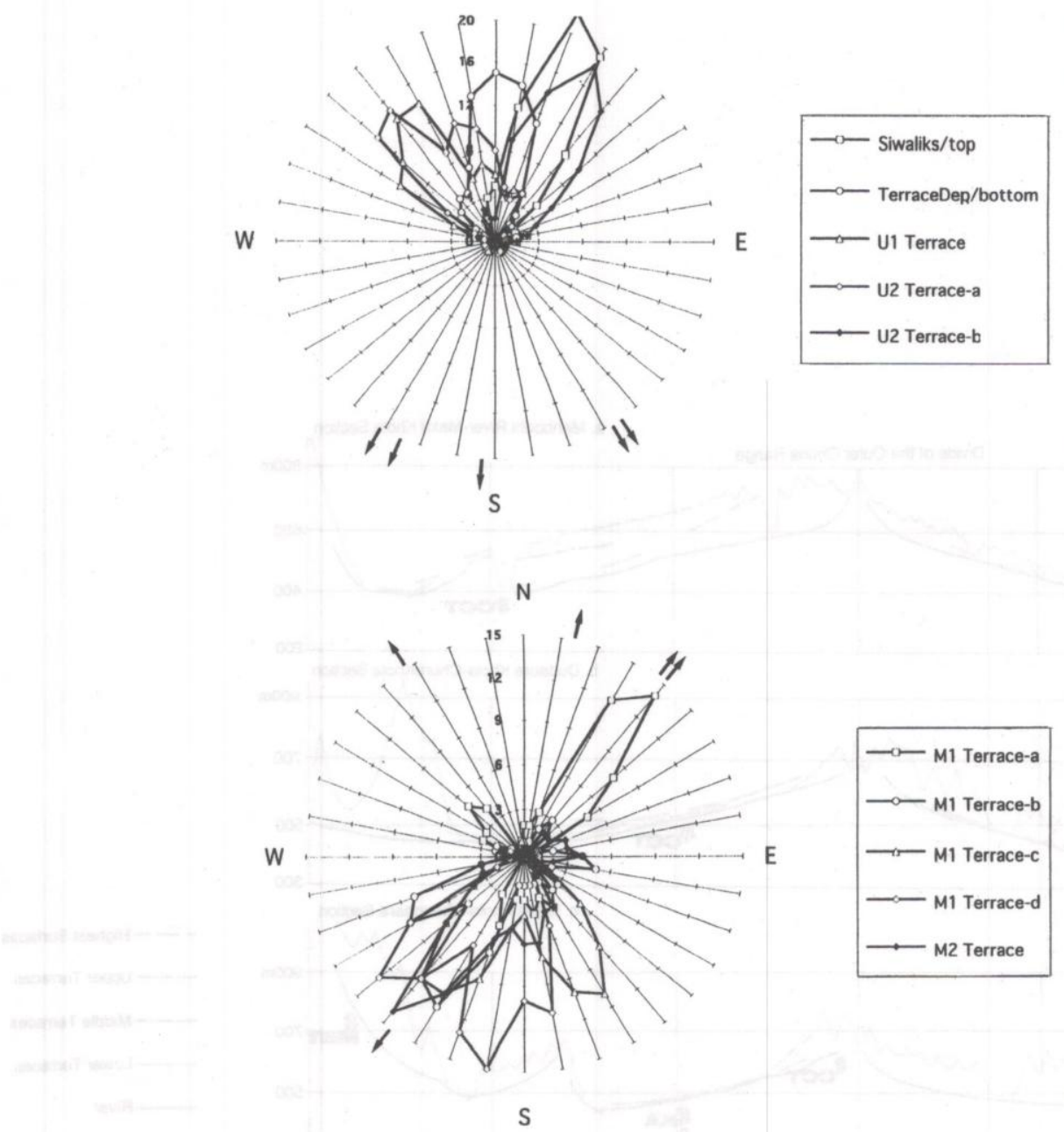

Fig. 5a Imbricate structures of the pre-Dun phase deposits (arrows indicate palaeocurrent directions Fig. 5b Imbricate structures of the separation phase deposits (arrows indicate palaeocurrent directions)

The Trisuli Fault was developed just behind the CCT with the same sense of movement indicating their genesis as a composite imbricate thrust system splaying off from the same detachment. Displacement along the Trisuli Fault was, delayed, however, and continued until the Middle Terrace Stage (the Last Glacial Stage).

Occurrence of lacustrine and swamp sediments in the Lower Terraces indicates the temporal interruption of the valley drainage system. The distribution of these nonfluvial deposits are limited along the upper stretches of the Karra Khola in the central part of the valley (Fig. 4). It seems likely that the Karra Khola Anticline had dammed up the streams in the beginning of the Dun Phase.

The Karra Khola Anticline has been evolving since the Last Glacial Stage. The Lower Terrace deposits change their amount of dip with folding. The older beds are inclined steeper whereas the younger sediments are offlapping the former deposits (Fig. 7). The amount of deformation, generated by this 


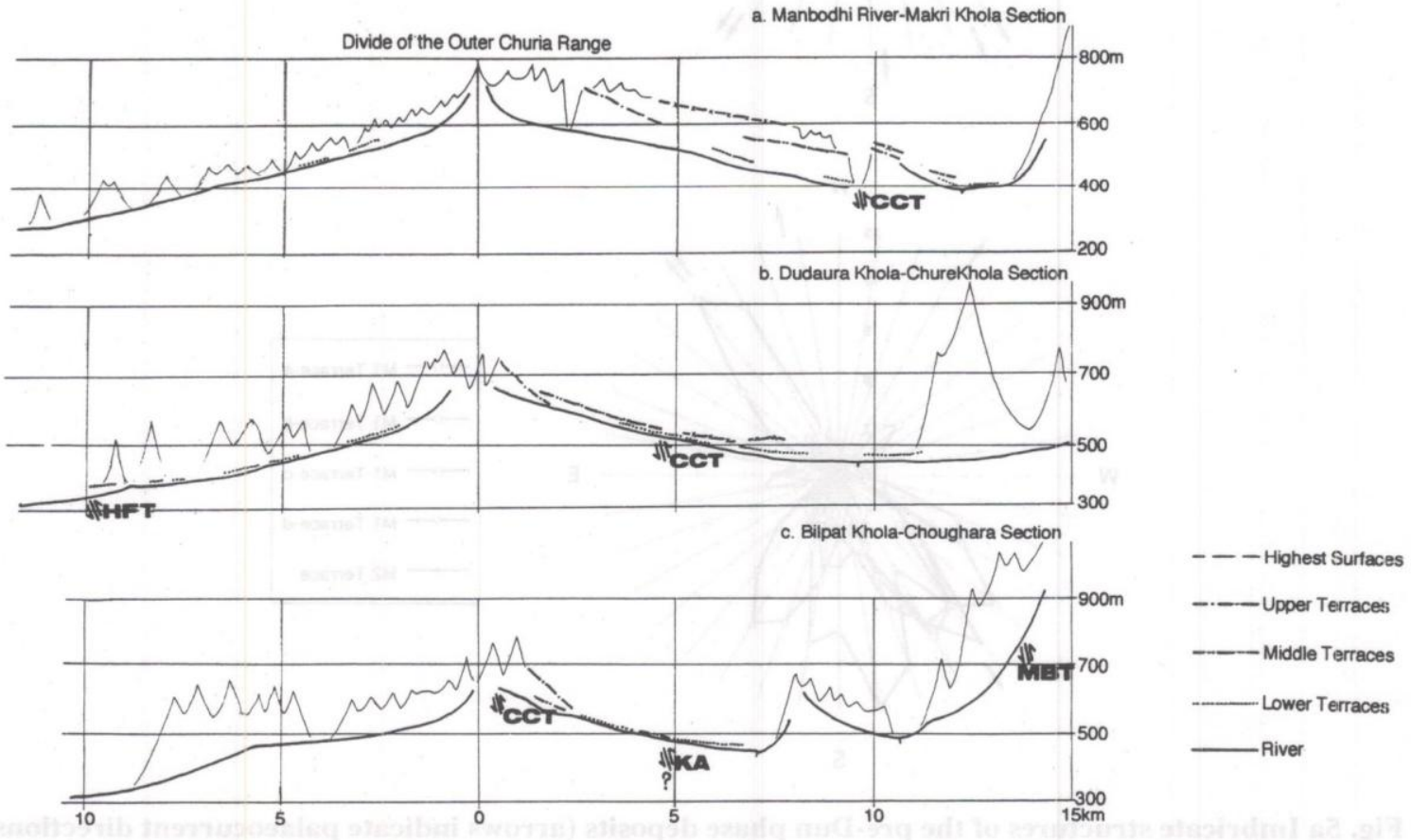

Fig. 6 Transverse profiles of the Hetauda Dun 
anticline, is comparable to that of the HFT. In both cases, these active structures have displaced the terrace surfaces by about $20 \mathrm{~m}$ since the Last Glacial Stage. Rapid-growing anticlines are occasionally regarded as by-products of blind thrusting (Stein and Yeats 1989). Some attributes of the Karra Khola Anticline, such as relationship with prior structures, magnitude of activity and maturities of the structure imply that it is an early stage of a fold-related thrusting. Thus, the post-separation tectonics of the Hetauda Dun are characterised by thrust-propagation towards the hinterland of the Himalayan Front.

\section{LOCAL TECTONICS AND STRESS FIELD}

The stress field of the Sub-Himalaya in Nepal is characterized by NNE-SSW shortening with a rightlateral slip of the Himalayan block, comprising the Great and Lesser Himalaya (Kizaki 1988).
In fact, the tectonic activity around Hetauda Dun is a record of continuing crustal shortening after the collision between the India and the Tibetan Plates. Even though the tectonic activity in the Dun valley has generated vertical displacement rather than lateral dislocations, the distribution pattern of the CCT and its related structures in a SW-bowed arc, indicates a clockwise rotation of the Inner Churia Range. The Hetauda Dun is developing between the northern and southern belts of the Siwaliks

\section{CONCLUSIONS}

The Late Quaternary morphotectonics of the Hetauda Dun is summarized as follows (Fig. 8):

(1) Upheaval of the Outer Churia Range caused the separation of the valley from the Gangetic Plain in the Last Interglacial Stage or the interstadial in the Last Glacial Stage. The major causes of this up-
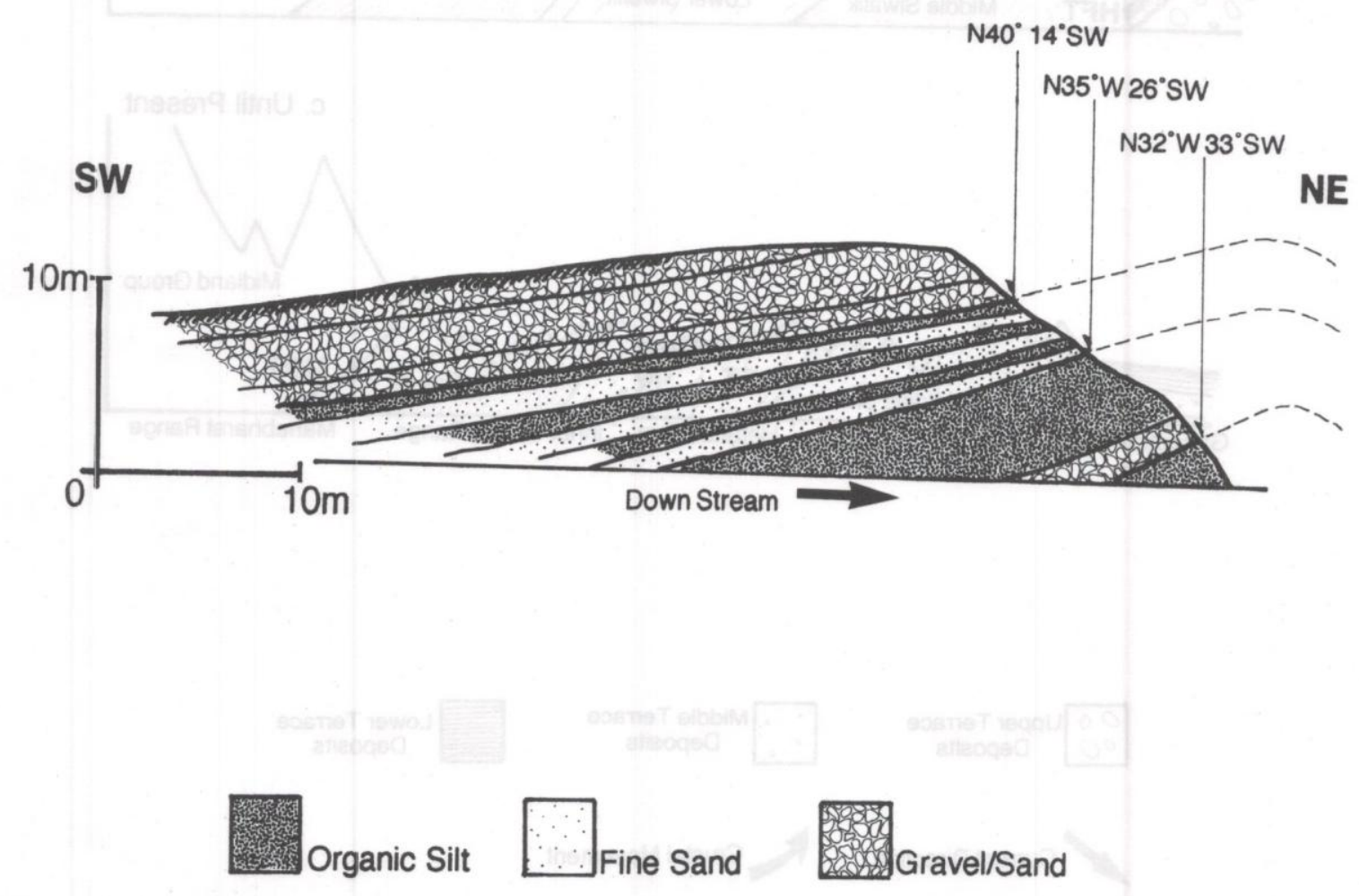

Fig. 7 A sketch of the Karra Khola anticline 
a. Until Middle Pleistocene

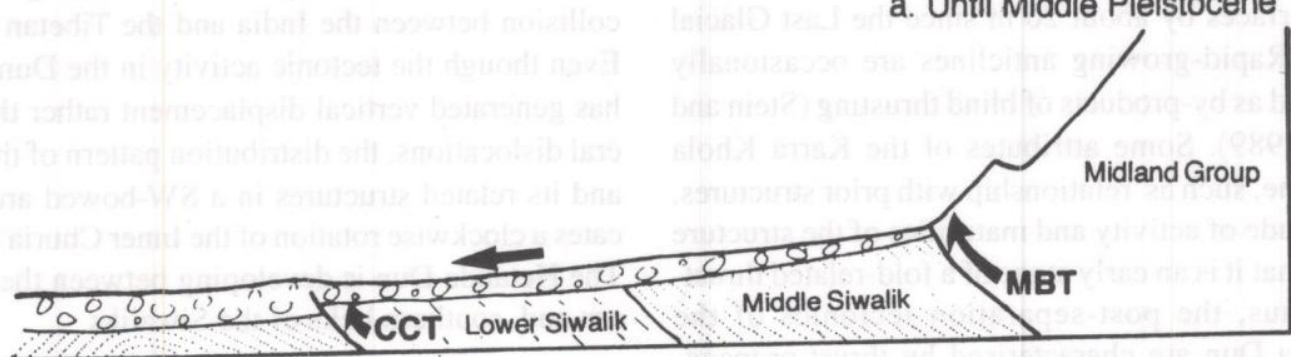

b. Last Inter Glacial / Last Glacial
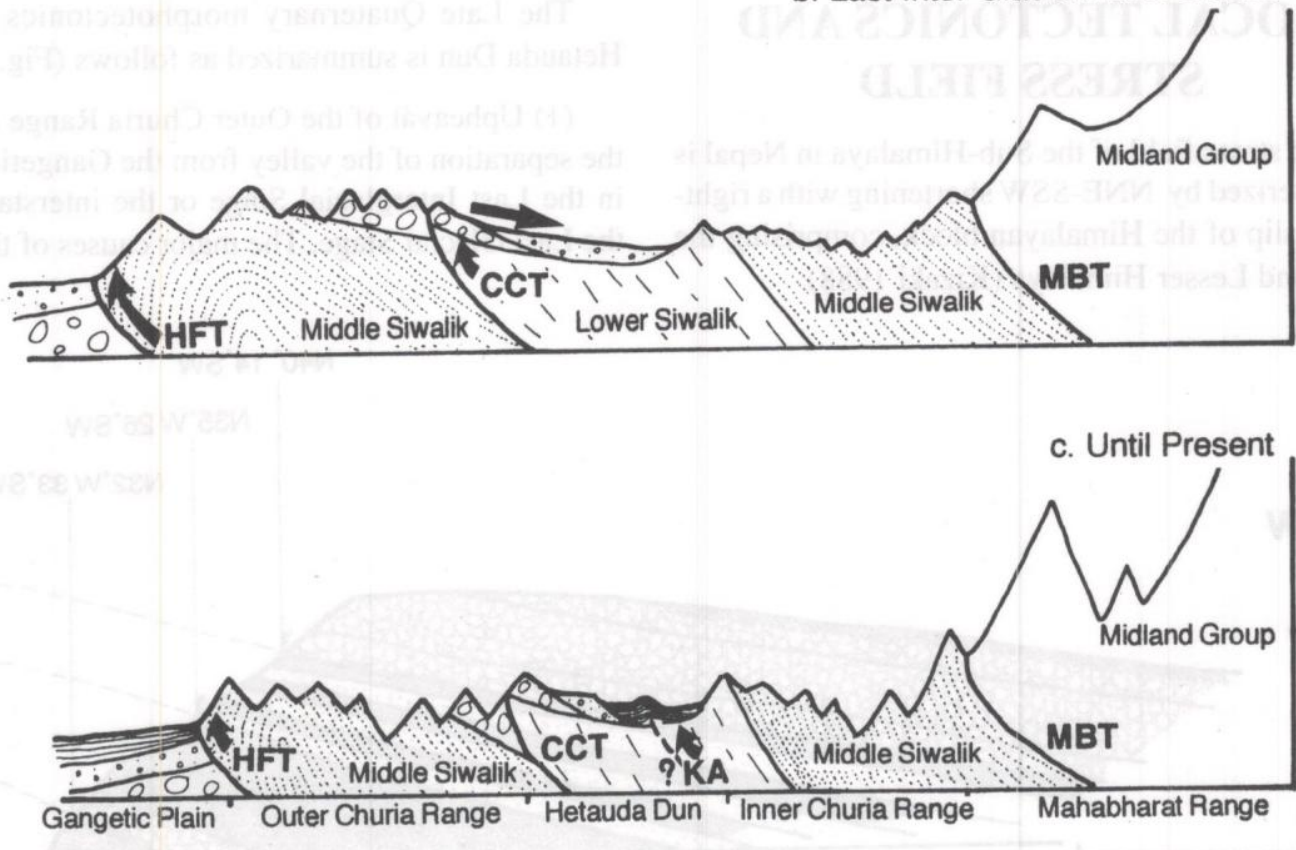

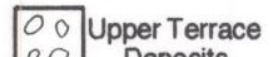

0 Deposits

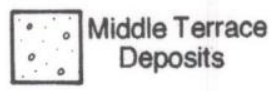

Crustal Movement

Current Direction

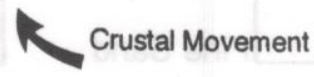

Fig. 8 Morphotectonic development of the Hetauda Dun 
Quaternary Morphotectonics of Hetauda Dun, Nepal

lift are the crustal shortening of the southern belt of the Siwaliks, with thrust migration towards the southern front of the Himalaya.

(2) Since the Last Glacial Stage, backward propagation of thrust imbrication has also occurred in the valley. These recent structures are parallel to the CCT and other tectonic lines. Thus, this crustal movement is evolving under the same stress field of the Separation and prior tectonic stages.

(3) The surface deformation is basically generated under NNE-SSW shortening tectonics, which are continuing after the collision between the Indian and Tibetan Plates. The regional sense of crustal movement, however, may have varied with time, including thrust propagation towards both the foreland and hinterland.

\section{ACKNOWLEDGEMENTS}

This paper is the result of an activity as a member of Japan Overseas Cooperation Volunteers (JOCV). I express my gratitude to Dr. V. Dangol, Chairman of the Department of Geology, TriChandra Campus, Tribhuvan University and all the staff of the department. I had useful discussions on neotectonics of the Sub-Himalaya with Dr. K. Kizaki, Dr. H. Yagi and Mr. F. Sawamura. Mr. T. Komatsubara gave me advice, assistance and encouragement during the research.

\section{REFERENCES}

Bashyal, R.; Delcaillau, B., Herail, G. and Mascle, G., 1989 Thrusting and orogenesis: the Himalayan Front in Central Nepal. Jour. Nepal Geol. Soc., v. 6, pp.1-9.

Kimura, K. (Submitted), River Terraces of Hetauda Dun, Central Nepal. Sci. Rep., Tohoku Univ.

Kizaki, K. (ed.), 1988, The Uplifting Himalayas (Joushou suru Himalayas, in Japanese). Tsukiji Syokan, Tokyo.

Nakata, T., 1972, Geomorphic History and Crustal Movements of the Foot-Hills of the Himalayas. Sci. Rep., Tohoku Univ., 7th Ser., v. 22, pp. 39-177.

Schelling, D., Cater, J., Seago, R. and Ojha, T.P., 1991, A Balanced Cross-Section Across the Central Nepal Siwalik Hills Hitaura to Amlekhganj. Jour. Fac. Sci. Hokkaido Univ., Ser. IV, v. 23, pp. 1-9.

Stein, R.S. and yeats R.S., 1989, Hidden Earthquakes. Science, 260,6 , pp. $48-57$.

Suppe, J., 1985, Principle of Structural Geology. Prentice-Hall, Engleood Cliffs, New Jersey.

Tokuoka, T., Takayasu, M., yoshida, M. and hisatome, K., 1986, The Churia (Siwalik) Group fo the Arung Khola area, West Central Nepal. Mem. Fac. Sci., Shimane Univ., v. 20, pp. 135-210.

Yamanaka, H. and yagi, H., 1984, Geomorphological Development of the Dang Dun, Sub-Himalayan Zone, Southwestern Nepal. Jour. Nepal Geol. Soc., v. 4, pp. 151-159,

Yeats, R.S. and Little, R.J., 1991, Contemporary Tectonics of the Himalayan Frontal Fault System: Folds, Blind Thrusts and the 1905 Kangra Earthquake. Jour. Structural Geol., v. 13, pp. 215-225. 